\title{
Culture as Politics: A Note on Language Legislation in Putin's Russia
}

\author{
Ingunn Lunde
}

\section{Introduction: culture as politics}

One of the goals of this volume, and of the conference that led to its compilation, is to highlight the significance of our fields, to show the world the ways in which languages - and modern language studies-are important; to demonstrate that language, history, culture, literature-and knowledge about these topics-are essential to society. Now, there are a variety of possible answers to the question "important to whom?" In this article, I will discuss some of the ways in which culture in general, and language in particular, has become an important focus of attention for the authorities in today's Russia - for a particular purpose. Over the last decade, Russian authorities have significantly increased their involvement in the field of culture, creating programmes for the patriotic education of citizens ("O programme" 2015), adopting new laws and regulations that apply to film, literature and art (Gorham \& Weiss 2016/17), and exploring the capital of culture for all it is worth (Schmid 2015). It is important to gain a firm grasp of the state's renewed interest in culture, in order to assess its impact in the broader context of Russian politics and society. In the following, I will discuss a few concrete examples of state involvement in the cultural sphere, focusing in particular on the question of language legislation.

"Culture" has in recent years entered state documents where one would think there was little room for it; for example, the latest Russian national security strategy, adopted on New Years Eve, 2015. Here, "culture" comes in as one of nine thematic sections, with a particular focus 
on the possible "dissolution of traditional Russian spiritual and moral values," which is represented as a threat to national security. The phrase "traditional spiritual and moral values" is repeated eleven times in the document and further specified as

the priority of the spiritual over the material, the protection of human life, human rights and human freedom, the family, constructive labour, service to the homeland, moral and ethical norms, humanism, compassion, justice, collaboration, collectivity, the historical unity of Russia's peoples, the continuity of Russian history. (Ukaz Prezidenta 2015)

These values, we learn, are threatened by Western values, which may be spread both through information campaigns and "poor-quality" foreign popular culture.

The phrase "traditional Russian spiritual and moral values" clearly echoes another state strategy document, the "Framework for a State Policy on Culture" signed by Vladimir Putin in December 2014, which emphasizes, in particular, the need to convey these values to the younger generation. The state policy on culture, we read, "is designed to ensure the strategic cultural and humanistic development as the foundation for economic prosperity, national sovereignty and the country's civilizational identity" (Osnovy 2014). ${ }^{2}$

The attention paid to the younger generations is particularly evident in the field of history and history teaching in schools. In 2013, President Putin launched the idea of a "universal history textbook," a retelling of Russian history free from ambivalences and diverging interpretations. The idea was a response to a series of controversies during the previous decade about the various history books used in schools and their representation of Russia's totalitarian past (Zvereva 2009). The debate reached a climax with the publication of a new series of textbooks in 2007 , the so-called Filippov books, named after one of their main authors. In their representation of the darker chapters of Soviet history, these books em-

1 For a systematic investigation of the concept of "spiritual-moral values" and its way from the political fringe to the centre of Russian public security debate, see Østbø 2016.

2 Here and in further quotations, translations are my own. 
phasized "positive results" and "necessary measures," while suppressing or belittling the situation of the victims of Stalinist repression. The public response to these books was mixed and ranged from active support to open letters of protest (Enstad 2011). After a few years work on a "universal history textbook," the idea was abandoned; meanwhile, a new "historical-cultural standard" has been agreed upon that will lay the foundation for a whole range of textbooks in several school subjects, and should "terminate the excessive intellectual disputes of the 199 os, the senseless 'pluralism' of opinions on the history of the country and the importunate ideologized interpretations of the most important historical events," as Minister of Culture Vladimir Medinskii expressed himself on the matter (Medinskii 2016).

A number of institutions have responded with great enthusiasm to the state's more pronounced involvement in the cultural sphere. 13 January 2015, the Military History Society posted the following statement on their homepage, signed by, among others, Deputy Prime Minister Dmitrii Rogozin, Minister of Culture Vladimir Medinskii and film maker Nikita Mikhalkov:

[...] We cannot lose the youth! We need a consolidation of state and society based on the values that our history has inseminated in us. We need a patriotic current in public consciousness. We need movies, books, exhibitions, modern video games, a patriotic Internet, patriotic radio and TV. Against us - and therefore against the truth - there's a new blitzkrieg. We need to support the president's course and launch an ideological counter-attack on all fronts-in this war for the peoples' minds. (Zaiavlenie 2013)

The Military History Society, together with other institutions and societies, has been instrumental in carrying out the five-year programmes for patriotic education that were initiated in the early 2000 and that have been extended for several periods. The programme features summer camps, courses, exhibitions and activities that give young people a sense of "belonging to Russia's great history and culture" (O programme 2015).

Policies related to both the culture documents and the national security strategy highlight the role of the Russian language, which is considered fundamental to Russian culture and history. Turning now to 
the field of language cultivation, linguistic regulation and legislation, it is evident that state involvement has been considerable for more than a decade. What is new in the linguistic policy of recent years is, once again, the turn towards culture.

\section{Language policy in post-Soviet Russia}

During the first post-Soviet decade, the state showed little interest in questions of language legislation. This changed with the turn of the century, and in 2005, The Russian Federation adopted a Law on the State Language of the Russian Federation, following years of lively debate, both within and outside parliament and government commissions. Research on both the debate and the law itself has convincingly demonstrated the ideological goals behind the legislative initiative, and how ideas about language policy are closely intertwined with notions of national identity and statehood (Ryazanova-Clarke 2006). Linguist Maksim Krongauz went so far as to call the 2005 law a "patriotic utterance" (Krongauz 2005). As stated above, the "patriotic" trend toward government involvement in the cultural sphere has grown stronger in recent years. With regard to language legislation, it is possible to sense, already in the process leading up to the 2005 law, a shift of focus away from questions about minority languages and linguistic rights, fields that sociolinguists usually refer to as status planning (and that had played a decisive role in late Soviet and early post-Soviet language legislation in the (former) Soviet republics). There was a move towards a greater emphasis on questions about standardization, norms and the nature and functional realms of Russian, questions that belong to the field of corpus planning. One of the most contested paragraphs in the discussions about the 2005 law concerned the norms of the standard language. It states:

6. When using Russian as the state language of the Russian Federation, it is forbidden to use words and expressions that do not comply with the norms of contemporary Russian standard language, with the exception of foreign words which do not have commonly used equivalents. (Zakon 2005)

As Lara Ryazanova-Clarke points out $(2006,49)$, the text reflects a very non-linguistic, unprofessional view of language, suggesting that "loan- 
words" either have "equivalents" or not, in which case they are acceptable. Furthermore, it refers to "the norms of the standard language" without specifying, but with a clear underlying assumption that such a concept is possible to define and refer to. While it is obvious that a legal document cannot set out the details of a definition on the same level as, for example, a scholarly linguistic text, the wording of the law's text seems to reflect an understanding of "the norms of the standard language" as a fixed and defined entity. At the same time, the concept emerges as a rather abstract notion of the highest variety of the language within a hierarchy of varieties. In other words, the text of the law reflects a linguistic culture informed by a standard language ideology in the sense of Lesley and James Milroy's conception of the standard language as an "idea in the mind rather than a reality - a set of abstract norms to which actual usage may conform to a greater or lesser extent" (Milroy \& Milroy 1985, 22-3).

Russia is indeed a country with a strong standard language ideology. Adherence to linguistic norms has traditionally played an important role in Russian language culture, which is also characterized by a strong tradition of linguistic cultivation, a centralized linguistic policy, the high status of normative and authoritative dictionaries and grammars, and the promotion of the one and only correct standard language in schools. With perestroika, glasnost and the subsequent breakup of the Soviet Union, shifting linguistic ideologies contributed to the questioning of the authority of the standard language. As a result, there was a strong tendency to relax the norm in official speech culture, in the mass media and in other written genres, including literature; and, with the advent of new media technology, in digital genres. The norms of the standard language were challenged by two main sources: a massive influx of words from English, the language of globalization; and a dissemination of "internal" loans from various non-standard varieties of Russian, such as jargon, slang, or verbal profanity. It is therefore not surprising that the language debates of the 1990 os and early 200 os were dominated by these two issues - foreign loanwords and non-standard varieties - and that the paragraph about the norms of the standard language was also among the most contested in discussions about the 2005 law. ${ }^{3}$

3 Research on post-Soviet language culture is growing, see Ryazanova-Clarke and Wade (1999), Krysin (2000-2012), Gorham, Lunde \& Paulsen (2014) and Gorham (2014) with bibliographies. 
The vagueness surrounding the definitions of "norm," "standard" and, for that matter, "state language" in the 2005 law becomes all the more obvious in view of the implementation of the law. Who is to decide whether a foreign word has a Russian equivalent? Who is to define whether a particular instance of language usage complies with "the norms of contemporary standard Russian?” Although linguistic expertise was drawn upon in specific cases (see Levontina 2005; Baranov 2007; Weiss 2008; 2009; Brinev 2009), the law on the Russian language seems to have been notoriously difficult to implement. Nevertheless, its role as part of the nationbuilding project of the Russian state from the 200 os onwards has been quite clear and as such, the law should be seen in the context of the many state initiatives promoting linguistic cultivation in the 2000 s. These include the "Russian Language" federal target programme (2002-2020), which has sponsored conferences and festivals on language-related topics, information campaigns, publications, TV and radio broadcasts; the internet site Gramota.ru (2000-), which offers authoritative grammati$\mathrm{cal}$ and lexical resources and an information service that as of May 2016 had received and answered more than 288,00o questions; the "Year of the Russian Language 2007," associated with numerous events in Russia and abroad promoting the study of Russian, as well as its status as an international means of communication, and many others.

\section{The 2014 anti-obscenity law}

In recent years, the trend has been to widen the contexts in which the use of the "state language" of the Russian Federation is required, and consequently, in which Russian, according to the law, has to "adhere to the norms of the standard language." These contexts now include essential cultural fora, such as literature, music and theatre. These latest amendments to the Law on the State Language of the Russian Federation took effect on 1 July 2014. They ban the use of obscene language in film, theatre and public performances of music or literature. The original 2005 law, as mentioned, already contained a passage forbidding "the use of words and expressions that do not comply with the norms of contemporary Russian standard language, with the exception of foreign words which do not have commonly used equivalents" (Zakon 2005). In the revised law, the phrase "including uncensored swearing" was added in brackets after "Russian standard language," and the law includes a set of new contexts 
where Russian has to adhere to these (revised) norms of the standard language: "in public performances of literature, art, folk art, in the form of theatre, cultural, educational and entertainment events" (Zakon 2014). Another important detail is that the original law contained a passage allowing for the use of non-normative language in contexts where this use "is an indispensable part of the artistic idea" (Zakon 2005). This passage has now been deleted.

The revised law does not prohibit writing, publishing or selling books or songs that contain non-normative words. What is forbidden is the performance of this kind of material publicly. However, books and audiovisual material with non-normative words have to include a notice warning of their content (e.g. "contains uncensored swearing"). Offenders face fines of up to 2,500 rubles for individuals and up to 50,000 rubles for organizations.

The question of where to draw the line between forbidden words and "only bad" but not forbidden expressions was hardly discussed, probably because this issue was considered to have been resolved by parliament's approval a year earlier of a law banning the use of profanity in mass media. In this instance, the Federal Service for Supervision of Communications, Information Technology and Mass Media (Roskomnadzor), with the help of linguists from the Russian Academy of Sciences' Russian Language Institute, produced a list of four words: khui, pizda, ebat' and bliad'. These words, and their large number of derivatives, are forbidden. ${ }^{4}$ In addition, the text of the new law refers to the use of "independent expertise" where there is any doubt. ${ }^{5}$

With the Russian language's rich resources for inflection, word formation and phraseological creativity, the actual possibilities for forming words and phrases based on these four roots are essentially without limits (see Plutser-Sarno 2001; 2005). This makes it all the more surpris-

4 The four words were listed in the letter from the linguists of the Academy of Sciences, whereas the mass media, where traditions of linguistic self-censorship were already strong, tended to use the circumscriptions found in Roskomnadzor documents: "The uncensored designation of the male sexual organ, the uncensored designation of the female sexual organ, the uncensored designation of the process of intercourse, and the uncensored designation of a woman of immoral conduct, and also all words formed of these linguistic elements." (Zykov and Kondrat'ev 2013). English equivalents would be 'cock', 'cunt', 'fuck' and 'slut'.

5 For general and specific discussions of the use of linguistic expertise in legal cases, see Levontina 2005, Baranov 2007, Weiss 2008; 2009, Brinev 2009. 
ing that the discussions of the proposed law in the parliament did not touch upon the difficult question of drawing lines between the forbidden and the tolerated. Several factors, such as euphemization or word play, may influence the meaning of a phrase that formally contains an obscene word; and, vice versa, vagueness or ellipsis may produce statements that clearly function as verbal profanity, but without using the actual forbidden word. ${ }^{6}$ Thus, the four-word list produced by Roskomnadzor clearly reflects a conception of language in which such instances of potential semantic ambiguity are not taken into account.

The motivations for proposing the new law were formulated in terms that the reader will recognize from my introductory remarks: the prohibition of verbal obscenity should safeguard the moral and spiritual standards of citizens, in particular those of children, as summed up by one of the bill's initiators, E.Ia. Rakhmatullina:

The present legislative proposal is, in fact, first of all aimed at the cultivation and protection of a healthy spirituality (dukhovnost') and morality, at the formation of a culture of speech and communication in contemporary society. In addition, one of the most important tasks today is the protection of the younger generation against attacks of anti-culture, also including the linguistic sphere, of phenomena that have a harmful effect on its morality and spiritual well-being. (Pervoe chtenie 2013)

This set of motivations fits well with the conservative values highlighted in Russia's recent initiatives in cultural policy, as evident in the "Framework for a State Policy of Culture" (Osnovy 2014), and reflects the general tendency towards stronger government involvement in the cultural sphere that I contextualized briefly above (see Kalinin 2015, Schmid 2015).

The law against verbal obscenity (usually called mat in Russian) has been widely discussed and debated in the mass media by politicians, journalists, linguists, writers, theatre directors and other artists. Arguments in favour of the law have tended to repeat the concern about

6 Levin (1996) provides a very useful categorization; see also Daniel Weiss' (2008) discussion with illustrative examples.

7 In a recent article, I have studied the reactions to this new law from people in the cultural field (Lunde 2017). 
moral standards, culminating in keywords such as bezdukhovnost' ("lack of spiritual culture") and bespredel ("lawlessness"), ${ }^{8}$ while arguments against it focused on the dangers of censorship in art. In addition, the usual Russian clichés about verbal obscenity were frequently heard, as emblematically expressed in filmmaker Nikita Mikhalkov's comment: "Russian obscenity (russkii mat) is one of the greatest and most subtle inventions of the Russian people, and impossible to translate into other languages" (Naralenkova 2014).

One may wonder why Mikhalkov, a strong supporter of president Putin who was one of the signees of the patriotic statement by the Military History Society (quoted above), comes in here too, now as a great supporter of Russian verbal obscenity. This has to do with the special status of obscenity among the non-standard linguistic registers of Russian. It not only enjoys authority and legitimacy among users with liberal attitudes towards linguistic variation and non-standard language, but is also endorsed by larger groups in society, including cultural and intellectual elites that otherwise support the hegemony of the standard language.

Writers, artists and cultural activists have either ignored the new law, not taking it seriously, or expressed their strong indignation, for example by organizing protests in the honour of verbal obscenity (Lunde 2017). The protests culminated in a nationwide event on 30 June 2014 where writers, actors, musicians and artists in nine Russian cities organized performances of texts, songs, films and plays that contain obscene language. At 11:59 pm, a moment of silence was held for verbal obscenity, before the new law took effect. One major ambition of such actions was to highlight the great significance of verbal obscenity in Russian culture and its implications; these dimensions of obscenity were felt to be reduced ad absurdum with the listing and banning of four words. The protest events tried to present verbal obscenity as something that cannot be isolated from the rest of the language and therefore constitutive of "Russian culture." For example, Zarema Zaudinova, theatre director and organizer of one of the protest events, explained that "Our cultural-mat action is not motivated by a wish to use obscene language, but to show that mat in art, in particular in literature, is a means of expression that allows one to disclose the essence of a phenomenon. It's a totally peaceful action by those

8 On this term and its broader context, see Gorham 2014, 93-97, Borenstein 2008 , 197-212. 
who love art and the Russian language [...]" (Panikhida 2014). It should be noted that Zaudinova labels the event kul'turno-maternoe meropriiatie, combining the two adjectives "cultural" and maternoe ("relating to mat"), and brings together mat and "the Russian language" in a relationship bordering on equivalency.

Online discussions about the law and the protest events stress that the question about mat in art and mat in everyday language is a question of two totally different kinds of obscenity: "We advocate 'cultural mat'. 'Literary mat', not abuse. Mat in art is something different. It's not vulgar abuse." (Stiazhkin 2014). Actor and artist Sergei Pakhomov plays openly on the quasi-sacred status of mat in Russian culture in his sarcastic comment on the law, and urges the authorities to go even further in the prosecution of "holy language":

I actually support the law on mat. For the simple reason that we get even more of those secret, sacred things. That is, when prohibited, mat becomes "holy mat," the language of the chosen ones. The fear of being punished for the use of mat words is, on the one hand, huge; on the other hand, there is no such fear at all. Until we have the first public execution for mat, it will remain in a semi-holy state, you know. But as soon as the first person is publicly executed for the use of mat, it will finally become a sacred language. (Karev et al. 2014)

This sarcastic stance illustrates the total lack of trust that characterizes the attitude of intellectuals, and more generally, of the "creative class," towards the authorities and lawmakers during the third presidency of Vladimir Putin. In this sense, the distinctive form of the protest events can also be linked to the wider context of protest culture in Russia today. In the autumn of 2011, when Putin's candidacy for a third presidential term was announced, many writers, artists, film-makers, journalists and intellectuals joined the wave of protests that followed, and, more gener-

9 "Creative class" is a term coined by Richard Florida (2002) and originally applied to the US, but which has gained currency in Russia as a label designating the emerging cluster of young, urban, educated people including cultural workers, creative professionals, journalists and entrepreneurs. A frequently debated concept (e.g. Saprykin et al. 2012), the term came to prominence during the post-election protests of 2011 and 2012 . 
ally, took a more active political stance than previously..$^{10}$ Since May 2012 , the intensified crackdown on free expression and the flood of new legislative measures limiting civil rights have significantly stifled the voices of dissent, including those of artists and intellectuals. Recourse to the kind of "creative responses" that were evident in the protests against the 2014 law (Lunde 2017) is also a direct consequence of distrust in the effectiveness (and even possibility) of more traditional means of protest and opposition. A potent mixture of sentiments-including concern for the freedom of art, strong emotions "on behalf of" verbal obscenity, and a generally playful and ironic style-informs the protest events, which together contribute a clear voice to the debate about verbal prohibition in the realm of culture.

\section{Concluding remarks}

The case of the 2014 anti-obscenity law reveals some of the problems involved when the cultural realm becomes subjected to official regulations. With the new laws of 2013 and 2014 banning obscene language in the mass media, film, literature and cultural performances, verbal prohibition has entered a new phase in Russia. The use of obscenity had been the object of legislative measures in post-Soviet Russia before 2013; it figures in $\$ 130$ of the Criminal Code on insults and in the Code of Administrative Offenses' $\$ 20.20$ on petty hooliganism. However, there is a crucial difference between using obscene language in an insult and using obscene language on stage or in a song, as part of an artistic representation. In the cases of insults and petty hooliganism, the obscene expressions are intentionally directed against a particular person in order to offend him or her. ${ }^{11}$ It is meant to be an insult, someone suffers and complains about it. This is not the case when profanity is used in the mass media and even less so when it figures in literature, film or theatre.

In the reactions to the 2014 law, there is a constant urge to demonstrate that obscene language used in artistic expression is fundamentally different from obscenity used in everyday life. Art is considered a special

10 For broader assessments of the role of art in protest movements in contemporary Russia, see Gabowitsch (2013) and Jonson (2015).

11 It is, of course, sometimes very difficult to prove whether verbal obscenity is used with the intention of offending, since it has so many other functions and meanings (see Levin 1996; Weiss 2008). 
case, and the new regulations are perceived as a gross violation of the right to define the conditions of artistic expression. At the crux of the matter are conflicting claims to the power to define culture, define language usage and define the conditions of artistic expression. The question of legislating the use of verbal obscenity is a particularly interesting one, since verbal obscenity is by many people obviously viewed as part of the "great Russian culture," on the one hand, but does not fit the state's conception of "spiritual and moral values" to be supported by its cultural policy, on the other.

\section{References}

Baranov, Anatolii. 2007. Lingvisticheskaia ekspertiza teksta: teoriia $i$ praktika, Moscow: Flinta.

Borenstein, Eliot. 2008. Overkill: Sex and Violence in Contemporary Russian Popular Culture. Ithaca/London: Cornell University Press.

Brinev, Konstantin. 2009. Teoreticheskaia lingvistika $i$ sudebnaia lingvisticheskaia ekspertiza. Barnaul: AltGPA.

Enstad, Johannes Due. 2011. "Putinistisk historiepolitikk: Oppussing av fortiden i Putins Russland.” Nordisk Østforum 15 (4):327-31.

Florida, Richard L. 2002. The Rise of the Creative Class: And How It's Transforming Work, Leisure, Community and Everyday Life. New York: Basic Books.

Gabowitsch, Mischa. 2013. Putin kaputt!? Russlands neue Protestkultur. Berlin: Suhrkamp.

Gorham, Michael S. and Daniel Weiss, eds. 2016/17. The Culture and Politics of Verbal Prohibition in Putin's Russia, special issue of Zeitschrift für slavische Philologie 72 (2)-73 (1).

Gorham, Michael S. 2014. After Newspeak: Language Culture and Politics in Russia from Gorbachev to Putin. Ithaca/London: Cornell University Press.

Gorham, Michael S., Ingunn Lunde and Martin Paulsen, eds 2014. Digital Russia: The Language, Culture and Politics of New Media Communication. London/New York: Routledge.

Kalinin, Il'ia. 2015. "Culture Matters: Why the Kremlin Wants to be the Keeper of Russia's Cultural Heritage." The Calvert Journal, 28 January, http://calvertjournal.com/comment/show/3608/Culture-mattersRussia-cultural-policy-Ilya-Kalinin (accessed 16 December 2016). 
Karev, Igor', Nataliia Mitiusheva, Iaroslav Zabaluev and Polina Ryzhova. 2014. "Pole bez brani." Gazeta.ru, 1 July, http://www.gazeta.ru/ culture/2014/07/01/a_6093465.shtml (accessed 30 June 2016).

Krongauz, Maksim. 2005. "Zametki rasserzhennogo obyvatelia." Otechestvennye zapiski 2, http://magazines.russ.ru/oz/2005/2/2005_2_4. html (accessed 16 December, 2016).

Krysin, Leonid, ed. 2000-12. Russkii iazyk segodnia, vols 1-5. Moscow: Azbukovnik.

Levin, Iurii. 1996. "Ob obstsennykh vyrazheniiakh russkogo iazyka." In Anti-mir russkoi kul'tury: iazyk, fol'klor, literatura, edited by Nikolai Bogomolov, 108-20. Moscow: Ladomir.

Levontina, Irina. 2005. "Bukva i zakon: sudebnaia lingvisticheskaia ekspertiza.” Otechestvennye zapiski 2, http://www.strana-oz.ru/2005/2/ bukva-i-zakon-sudebnaya-lingvisticheskaya-ekspertiza (accessed 16 December, 2016).

Lunde, Ingunn. 2017. “Abanamat": Reactions From the Cultural Field to the 2014 Russian Anti-Obscenity Law," Zeitschrift für slavische Philologie 73 (1): 1-29.

Medinskii, Vladimir. 2016. "Est li u pravdy versii?" Rossijskaia gazeta, 18 February, http://rg.ru/2016/o2/18/medinskij-edinyj-uchebnikistorii-prekratit-intellektualnuiu-mezhdousobicu.html (accessed 16 December, 2016).

Milroy, James and Lesley Milroy. 1985. Authority in Language. London/ New York: Routledge.

Naralenkova, Ol'ga. 2014. "Mikhalkov vystupil protiv total'nogo zapreta mata v kino.” Rossiiskaia gazeta, 28 June, http://www.rg.ru /2014/o6/28/mmkf-site.html (accessed 16 December 2016).

O programme. 2015. "O gosudarstvennoi programme 'Patrioticheskoe vospitanie grazhdan Rossiiskoi Federatsii na 2016-2020 gody'." Pravitelstvo RF, Postanovlenie No. 1493, 2015, http://government. $\mathrm{ru} /$ media/files/8qqYUwwzHUxzVkH1jsKAErrx2dE4qows.pdf (accessed 16 December, 2016).

Osnovy. 2014. "Osnovy gosudarstvennoi kul'turnoi politiki." http:// news.kremlin.ru/media/events/files/41d526a877638a8730 eb.pdf (accessed 16 December, 2016). 
Østbø, Jardar. 2016. “Securitizing 'Spiritual-Moral Values’ in Russia.” PostSoviet Affairs 32. http://dx.doi.org/10.1080/1060586X.2016.1251023 (accessed 16 December 2016).

Panikhida. 2014. "Panikhida po matu: v Barnaule zavtra prostiatsia s krepkimi vyrazheniiami." Politsib.ru, 29 June, http://www.politsib. $\mathrm{ru} /$ news/72233 (accessed 30 June 2016).

Pervoe chtenie. 2013. "O proekte federal'nogo zakona 'O vnesenii izmenenii v stat'iu 3 Federal'nogo zakona "O gosudarstvennom iazyke Rossiiskoi Federatsii"' i otdel'nye zakonodatel'nye akty Rossiiskoi Federatsii v sviazi s sovershenstvovaniem pravovogo regulirovaniia v sfere ispol'zovaniia russkogo iazyka." Transcript from the Duma hearings, 12 April, http://api.duma.gov.ru/api/transcript/190238-6 (accessed 16 December 2016).

Plutser-Sarno, Aleksei. 2001. Bol'shoi slovar' mata: opyt postroeniia spravochno-bibliograficheskoi bazy dannykh leksicheskikh i frazeologicheskikh znachenii slova 'khui'. St Petersburg: Limbus.

Plutser-Sarno, Aleksei. 2005. Bol'shoi slovar' mata: opyt postroeniia spravochno-bibliograficheskoi bazy dannykh leksicheskikh i frazeologicheskikh znachenij slova 'pizda'. St Petersburg: Limbus.

Ryazanova-Clarke, Lara. 2006. “'The State Turning to Language’: Power and Identity in Russian Language Policy Today." Russian Language Journal 56:37-55.

Saprykin, Iurii, Igor' Mal'tsev, Arsenii Zhiliaev and Denis Boiarinov. 2012. "Kreativnyi klass v Rossii: kto vse eti liudi?" Colta.ru, 28 August, http://archives.colta.ru/docs/4829 (last accessed 30 June 2016). Schmid, Ulrich. 2015: Technologien der Seele: vom Verfertigen der Wahrheit in der russischen Gegenwartskultur. Berlin: Suhrkamp.

Stiazhkin, Denis. 2014. "Chtetsy v zashchitu mata v iskusstve-'Abanamat' (foto)." LiveJournal blog Vestnik svobody, 1 July, http://styazshkin. livejournal.com/988578.html (accessed 6 June 2016).

Ukaz Prezidenta 2015. "Ukaz Prezidenta Rossiiskoi Federatsii ot 31 dekabria 2015 goda N 683 'O Strategii natsional'noi bezopasnosti Rossiiskoi Federatsii'.” Rossiiskaia gazeta, 31 December, https:// rg.ru/2015/12/31/nac-bezopasnost-site-dok.html (accessed 16 December 2016). 
Weiss, Daniel. 20 o8. "Umestno li nakazyvat' za publichnoe upotreblenie mata? Obshchestvennoe mnenie i zdravyi razum lingvistov." ScandoSlavica 54:198-222.

Weiss, Daniel. 2009. "Sudebnaia ekspertiza i vklad lingvista v interpretatsiiu zakona." In From Poets to Padonki: Linguistic Authority and Norm Negotiation in Modern Russian Culture (Slavica Bergensia 9), edited by Ingunn Lunde and Martin Paulsen, 252-74. Bergen: Department of Foreign Languages.

Zaiavlenie 2013. "Zaiavlenie Rossiiskogo voenno-istoricheskogo obshchestva." http://histrf.ru/rvio/activities/news/item-1378 (accessed 16 December, 2016).

Zakon 2005. "Zakon o gosudarstvennom iazyke Rossiiskoi Federatsii." http://www.gramota.ru/spravka/docs/16_3 (accessed 16 December, 2016).

Zvereva, Galina. 2009. "Die Konstruktion einer Staatsnation: Geschichtslehrbücher für das neue Russland." In Geschichtspolitik und Erinnerungskultur im neuen Russland, edited by Lars Karl and Igor J. Polianski, 87-118. Göttingen: VઐR unipress.

Zykov, Vladimir and Aleksandr Kondrat'ev. 2013. "Roskomnadzor nakazhet SMI tol'ko za chetyre maternykh slova." Izvestiia, 25 December, http://izvestia.ru/news/563178 (accessed 16 December, 2016). 